ppi $201502 Z U 4645$

Esta publicación cientifica en formato digital es continuidad de la revista impresa ISSN-Versión Impresa 0798-1406 / ISSN-Versión on line 2542-3185Depósito legal pp

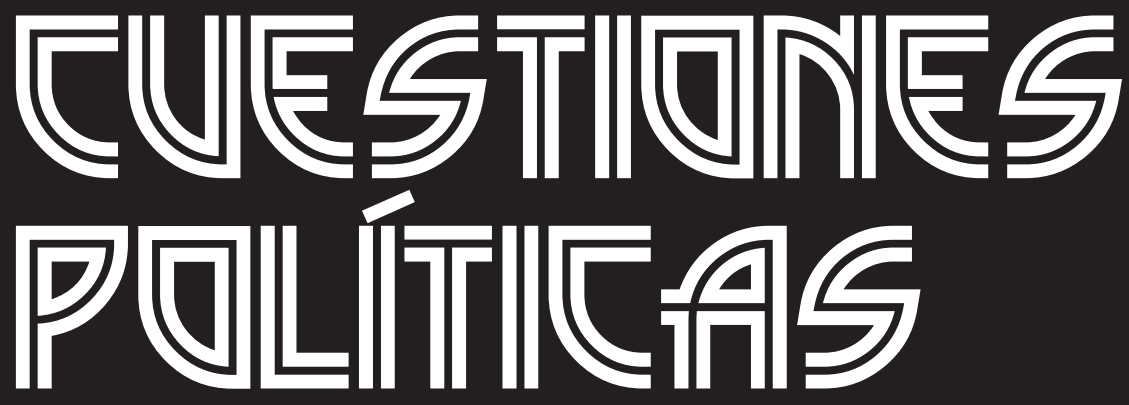

Instituto de Estudios Políticos y Derecho Público "Dr. Humberto J. La Roche' de la Facultad de Ciencias Jurídicas y Políticas de la Universidad del Zulia Maracaibo, Venezuela
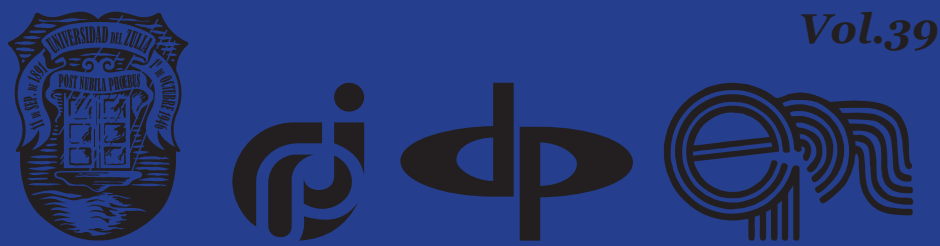


\title{
Investigation of sexual crimes against children
}

\author{
DOI: https://doi.org/10.46398/cuestpol.3968.42
}

\author{
Yuliia Chornous * \\ Hanna Nikitina-Dudikova ** \\ Olena Lepei $* * *$ \\ Anastasiia Antoniuk **** \\ Mariia Fridman-Kozachenko *****
}

\section{Abstract}

Through a documentary methodology close to legal hermeneutics, the article reveals the main problematic aspects of the detection, investigation, and combat of crimes against sexual freedom and the inviolability of children, as well as highlights the main positions of the European Court of Rights in this regard. Ukraine is currently actively discussing the prospect of a comprehensive and stable juvenile justice system, so protecting the rights of the child from the usurpation of sexual freedom and inviolability is an important part of ensuring its functioning. The work aims to establish the characteristics of detection, investigation, and prevention of crimes against the freedom and sexual inviolability of the child and, suggest ways to solve the main problems. The result of this work is to identify specific features of the detection, investigation, and combat of crimes against the freedom and sexual inviolability of the child, while determining the importance of investigative and preventive actions considering the psychological characteristics of children, proposing ways to improve the existing system of protection of sexual crimes. It is concluded that the prevention of these crimes requires multidimensional legal and political action.

* Doctor of Legal Sciences, Professor, Professor of Department of Criminalistics and Forensic Medicine, National Academy of Internal Affairs. ORCID ID: https://orcid.org/oooo-00o1-9710-4858. Email: chornous@ukr.net

** PhD in Law, Associate Professor of Department of Criminalistics and Forensic Medicine, National Academy of Internal Affairs. ORCID ID: https://orcid.org/oooo-0002-8865-0061. Email: annanikitinadudikova@gmail.com

*** PhD in Law, Associate Professor, Professor at the Department of Criminal Procedure, National Academy of Internal Affairs. ORCID ID: https://orcid.org/oooo-0002-0348-3170. Email: Elena031077@gmail. com

**** Ph. D. in Law, Associate Professor of the Department of Criminal Procedure and Criminology, University of the State Fiscal Service of Ukraine. ORCID ID: http://orcid.org/oooo-0001-8916-3575. Email: anastasiaana0502@gmail.com

***** Ph. D. in Law, Associate Professor of the Department of criminal procedure and criminology, University of the State Fiscal Service of Ukraine. ORCID ID: https://orcid.org/oooo-0oo3-1154-8170. Email: mariiafridman@gmail.com 
Keywords: juvenile justice; offences against the sexual freedom and inviolability of the child; research actions; preventive measures; justice in Ukraine.

\section{Investigación de delitos sexuales contra niños}

\section{Resumen}

Mediante una metodología documental próxima a la hermenéutica jurídica, el artículo revela los principales aspectos problemáticos de la detección, investigación y combate de los delitos contra la libertad sexual y la inviolabilidad de la niñez, así como resalta las principales posiciones de la Corte Europea de Derechos al respecto. En la actualidad, Ucrania está debatiendo activamente la perspectiva de un sistema de justicia juvenil amplio y estable, por lo que proteger los derechos del niño de la usurpación de la libertad e inviolabilidad sexuales es una parte importante para garantizar su funcionamiento. El trabajo tiene como objetivo establecer las características de detección, investigación y prevención de los delitos contra la libertad e inviolabilidad sexual del niño y, sugerir formas de resolver los principales problemas. El resultado de este trabajo es lograr identificar rasgos específicos de la detección, investigación y combate de los delitos contra la libertad e inviolabilidad sexual del niño, determinando al mismo tiempo la importancia de las acciones investigativas y preventivas teniendo en cuenta las características psicológicas de los niños, proponiendo formas de mejorar el sistema existente de protección de delitos sexuales. Se concluye que la prevención de estos delitos requiere de una acción multidimensional jurídica y política.

Palabras clave: justicia de menores; delitos contra la libertad sexual e inviolabilidad del niño; acciones de investigación; medidas preventivas; justicia en Ucrania.

\section{Introduction}

The state, which positions itself as legal, democratic, and social, must direct the vectors of policy development to ensure decent living conditions for people and citizens regardless of their age. However, given that the child, due to the extent of his legal personality, in particular, legal capacity, cannot adequately protect his rights and freedoms without the assistance of legal representatives, the state should be focused on creating an effective mechanism for protection of rights and interests of the child. 
Yuliia Chornous, Hanna Nikitina-Dudikova, Olena Lepei, Anastasiia Antoniuk y Mariia Fridman-Kozachenko

Noting in Article 3 of the Constitution of Ukraine (Law 27-IX /1996) that a person, his life and health, honor and dignity, inviolability, and security are recognized in Ukraine as the highest social value, the state has committed itself to all available legal means and ways to protect the person, including the child. The Basic Law provides for the state protection of children, the equality of children in their rights, regardless of origin, or whether they are born in or out of wedlock, and states that any violence against and exploitation of a child is prosecuted. Part 1 of Article 10 of the Law of Ukraine "On Child Protection" (Law 2402-III/2001) states that every child is guaranteed the right to liberty, the security of person, and protection of dignity.

The topic of protection of children's rights is also widespread in the international community. Thus, a special place in the regulation of children's rights is occupied by the 1989 UN Convention on the Rights of the Child and the European Convention for the Protection of Human Rights and Fundamental Freedoms (United Nations, 1950) (the Convention), the Council of Europe Convention on the Protection of Children against Sexual Exploitation and Sexual the rights of the child concerning child trafficking, child prostitution, and child pornography.

Thus, Article 19 (1) of the UN Convention on the Rights of the Child (United Nations, 1989) provides that States Parties shall take all appropriate legislative, administrative, social, and educational measures to protect the child from all forms of physical or mental violence, injury or abuse, neglect or negligent treatment, maltreatment or exploitation, including sexual abuse, while in the care of parent(s), legal guardian(s) or any other person who has the care of the child.

Article 3 of the Optional Protocol to the Convention on the Rights of the Child on the sale of children, child prostitution and child pornography (United Nations, 2000) provides that each State Party shall ensure that, at least, the offer, transfer, or receipt by any means of sexual exploitation children; offering, receiving, transferring or providing a child for the purposes of child prostitution as defined in Article 2; the production, distribution, import, export, supply, sale or storage for the above purposes of child pornography as defined in Article 2 are fully covered by criminal law, whether committed at the national or transnational level or individually or in an organized manner.

This indicates a high level of interest of the international community in establishing the most accurate regulation of violations in the field of sexual exploitation of children in order to prevent them.

Include in a paragraph the objective of the article and the importance of the research. 


\section{Methodology of the study}

Various methods of scientific cognition were used to write the article. Thus, the dialectical method revealed the general properties, connections, and patterns that arise in the detection, investigation, and prevention of crimes against sexual freedom and inviolability of the child.

Further, the formal-legal method helped to clarify the essence and content of legal norms, their functions, features of the concepts they define, and the processes they regulate, within the research topic.

The analysis and synthesis made it possible to provide a general description and characterization of the features of detection, investigation, and prevention of crimes against sexual freedom and inviolability of the child, to identify and compare basic positions on the legal regulation of relations related to violations of children's rights. The synthesis also served as a basis for combining original ideas, principles, developments for their further effective use in legal relations arising from the crimes of a sexual nature against children.

Moreover, the hermeneutic method allowed, based on acquaintance with texts of normative and doctrinal sources, to investigate the maintenance of separate legal norms and theoretical provisions in the context of actual questions of protection of the rights of the child to inviolability and sexual freedom. Thanks to the comparative-legal method, it has become possible to compare the main legal positions of the ECtHR, considering the specifics of each case.

Generalization, as a method, made it possible to identify the main problems and vectors of development in ensuring the protection of children's rights within the formation of juvenile justice. The logical-legal method was used to formulate proposals for the further development of juvenile justice, taking into account the counteraction and investigation of crimes against sexual freedom and inviolability of children.

All research methods were interconnected and complementary.

\section{Analysis of recent research}

Some works by domestic and foreign scientists are devoted to the protection of the child's rights arising from the commission of crimes against sexual freedom and inviolability. Thus, Dudorov (2018) paid much attention to the general characteristics of crimes against sexual freedom and inviolability of the person, and the coverage of the main features of each specific crime within the relevant category. 
Yuliiia Chornous, Hanna Nikitina-Dudikova, Olena Lepei, Anastasiia Antoniuk y Mariia Fridman-Kozachenko

670

Investigation of sexual crimes against children

Dzhuzha (2009) focused on the prevention of sexual crimes, primarily by law enforcement. The researcher noted that preventive measures should be taken with potential offenders, children, as well as their parents / legal representative.

A joint study by Denisovskyi and Fedchak (2018) was aimed at identifying the main shortcomings of the existing system of preventive measures to commit sexual crimes against children and suggest ways to overcome them, in particular, through appropriate methodological and financial support.

At the same time, Ortynskyi et al. (2018) studied the general aspects of crime investigation in Ukraine.

At the same time, the reasons for the high level of latency of crimes against sexual freedom and inviolability of the child, the application of the practice of an international judicial institution, the peculiarities of investigative actions in the examination of these crimes, and the establishment of a system of bodies and measures to prevent child sexual abuse character.

\section{Results and discussion}

Global trends in the development of criminal law on liability for sexual crimes are both its consistent liberalization (manifested in the decriminalization of adultery, seduction, voluntary homosexuality) and the elimination of gender inequality, and strengthening criminal protection of children from various forms of sexual violence and sexual exploitation.

It should be noted that the sexual freedom and/or sexual integrity of a person are subject to many crimes under current criminal law. Some of them concern exclusively the commission of appropriate actions concerning a minor, others do not have a specially identified victim.

Thus, sexual freedom and inviolability are generic objects of the following crimes:

- rape (Article 152 of the Criminal Code of Ukraine (hereinafter - the Criminal Code (Law 2147a-VIII/ 2001).

- sexual violence (Article 153 of the Criminal Code).

- coercion to have sexual intercourse (Article 154 of the Criminal Code).

- sexual intercourse with a person who has not reached the age of sixteen (Article 155 of the Criminal Code), and;

- depravity of minors (Article 156 of the Criminal Code). 
Besides, violations of sexual freedom and inviolability are also accompanied by such crimes as an encroachment on morality (Articles 301-303 of the Criminal Code), coercion to engage in prostitution (Part 1 of Article 303 of the Criminal Code), trafficking in human beings (Article 149 of the Criminal Code), committed for sexual exploitation, etc.

Dudorov (2018) notes that sexual freedom should be understood as the right of a person to independently choose a partner for sexual intercourse, a form of such intercourse, and not to allow any coercion in this area. An adult (in the context of the Criminal Code, is a person who has reached the age of 16 , not a person who has reached a certain age for marriage) and a mentally healthy person determines with whom and in what way he will satisfy his sexual needs.

If sexual freedom is associated with a person's ability to control himself or herself in the area of sexual intercourse, then sexual integrity means a legally protected condition that prohibits sexual intercourse with a person who for certain reasons (for example, under the age or mental illness) is not a carrier of sexual freedom. Sexual integrity, being an absolute concept, means that certain interests of an inviolable person cannot, under any circumstances, be violated by another subject, and sexual acts committed against him/her are recognized as criminally punishable.

Thus, sexual freedom and sexual integrity of a person are conceptsantipodes that are independent in nature and do not intersect.

There are significant problems in Ukraine with the detection of such crimes, resulting in the classification of crimes against sexual freedom and inviolability as latent. According to the author, a significant percentage of latency of sexual crimes is due to several reasons. The first, and unconditional, reason should be considered the lack of the child's necessary capacity to protect their violated rights. Thus, a child can turn to one of the legal representatives who are obliged to represent the interests of the child, in which adults often do not accept the child's stories and consider them fictional, and therefore do not take the necessary measures, including not resorting to appropriate state-authorized bodies.

There are likely cases of adults committing crimes against children due to Soviet and, in some cases, post-Soviet upbringing, when reporting sexual violence, especially in the family, was inconvenient and embarrassing because it increased public condemnation.

The psychological and psycho-emotional development of a child who suffers from sexually motivated crimes also plays an important role in detecting sexual crimes where the victims are children. Thus, depending on age, development, and upbringing, the child may not understand the nature of the actions committed against him/her and therefore may consider the situation of sexual violence to be normal. 
Yuliia Chornous, Hanna Nikitina-Dudikova, Olena Lepei, Anastasïa Antoniuk y Mariia Fridman-Kozachenko

It should be agreed with Shapovalov (2017) that the pre-trial investigation begins from the moment of registration of information about the fact of the committed crime in the Unified register of pre-trial investigations. However, the grounds for initiating criminal proceedings may be both the victim's appeal and the materials of the operational units. Until the start of the pre-trial investigation, law enforcement officers are taking several measures to identify the facts of criminal activity.

Thus, the key point in detecting crimes against sexual freedom and the inviolability of the child is the close cooperation of law enforcement agencies with teachers of educational institutions, guardianship authorities and other bodies called upon to monitor the rights of the child.

A negative consequence of the development of modern society has been the rethinking of many things, including the modification of consciousness regarding the perception of the child as such. The rapid pace of adulthood, which is currently observed in modern society, according to the author, leads to an increase in the number of offenses against sexual freedom and inviolability of children.

Investigations of crimes against sexual freedom and the inviolability of the child are also characterized by certain features. It should be noted that such crimes have a negative impact on the psychological state of the child, and therefore it is necessary to carry out appropriate investigative actions, taking into account the circumstances of the situation.

Thus, an important place among the priority investigative actions is occupied by the interrogation of the injured child.

In accordance with part 1, 2 of Article 226 of the Criminal Procedure Code of Ukraine (Law 4651-VI/2012 of April 13), the interrogation of a minor or a minor is conducted in the presence of a legal representative, teacher, or psychologist, and if necessary - a doctor. The interrogation of a minor may not continue without a break for more than one hour, and in general for more than two hours a day.

Given the specificity of the crimes committed against the child, the interrogation should take the form of a conversation with the child, a survey. In this case, if there is a possibility of a crime against the child by one of the legal representatives, their presence should be excluded. The need to talk to the child is explained by the fact that mainly the child's statements and behavior are the main means of determining whether sexual violence has occurred.

Human (2016) emphasizes that to create a trusting atmosphere of a child's conversation with a law enforcement officer, such a conversation should take place in a place that the child considers "safe." It is important that in some Belarusian cities there are already children's bar associations, 
and in the Baltic States there are special offices where children victims of violence in comfortable psychological conditions have the opportunity to tell in detail, to show with toys what happened to them. A video of such a consultation will be broadcast later during the court hearing.

According to the author, it is also possible to change the person who will conduct the interrogation, as the creation of favorable conditions for establishing the circumstances of the case depends on personal relationships and friendly children to the interrogator.

It is also important to remember that the child's interrogation should be as concise and meaningful as possible. The fact is that with each subsequent story of the child about violence against him increases the risk of confusing testimony and distortion of facts, which devalues the quality of interrogation as an investigative action. Conducting timely and high-quality interrogation will help minimize the number of interviews with the child in the future, record the child's testimony within the statutory period, protect the child's psyche from re-emotional experience of the crime and provide an opportunity to begin rehabilitation with the child as soon as possible.

It is also important to conduct a medical examination of the child. Views on the appropriateness of medical examination have changed significantly in recent years. Experts had many reservations about the appropriateness of medical examinations of children who have been sexually abused because of their ability to harm the child and because the likelihood of favorable medical conclusions was generally remote.

However, the author is convinced that a medical examination is necessary, because in its absence to claim a full and comprehensive investigation of the crime, the collection of all possible evidence is not possible, which contradicts the requirements and objectives of criminal proceedings.

Parents or other legal representatives who are constantly with the child should also be interviewed to gather additional information about the alleged crime, to find out their role in prompting the child to make or deny the charges, to determine whether one of them is involved in the crime, and so on. Besides, a conversation with legal representatives will help to learn about the normal behavior of the child, which when applied to violence changes, because it has clear signs of psychological abuse.

It is not uncommon for a child to know the person who committed the crime. In this case, it is important to immediately detain and interrogate the potential offender.

Also, in the investigation of crimes against sexual freedom and the inviolability of the child, a mandatory risk assessment should be carried out. If professionals determine that a child is at risk of future sexual, physical, or emotional abuse, then a plan must be developed to protect him/her. 
Yuliia Chornous, Hanna Nikitina-Dudikova, Olena Lepei, Anastasïa Antoniuk y Mariia Fridman-Kozachenko

It is not an exception to use investigative actions in the investigation of the above-mentioned crimes, such as presenting a person for identification, presenting things for identification, investigative experiment, but due to the special psychological subtext, they should be carried out carefully and in exceptional cases.

At the same time, the ineffective pre-trial investigation and trial of cases of sexual offenses against children become grounds for the European Court of Human Rights to recognize violations of the provisions of the Convention by States. Cases, related to the need to protect children from sexual violence, have generally had a major impact on the development of ECtHR practice, which covered both the scope of Article 8 of the Convention and the concept of positive obligations of the state in connection with the signing of this international treaty.

Thus, in X. and Y. v. The Netherlands (26 March, 1985), the ECtHR gave a detailed description of the scope of Article 8 of the Convention, according to which the concept of "private life" refers to a person's physical and moral integrity, in particular his or her sexual life.

Also, this case should be considered indicative, as it can be considered as one of the driving forces for the revision of the national laws of the signatory states to the Convention. Thus, X. and Y. v. The Netherlands concerned sexual abuse of a mentally handicapped 16-year-old girl, and the complaint lodged by her father was upheld by the police but was subsequently rejected by the court because the relevant article of national law could be applied only if directly to the victim. The ECtHR acknowledged that the protection provided by Dutch law was insufficient in the case of such an unlawful act to which Y. was subjected, and after analyzing the criminal law in force at the time, the ECtHR stated that the State did not provide adequate practical and effective - protection and found a violation of Article 8 of the Convention.

The ECtHR recognizes sexual crimes committed against children as serious acts that threaten the basic values and aspects of private life. Moreover, even in cases where there has been no actual physical violence, the ECtHR dares to establish that the domestic law of a State party to the Convention complies with the provisions of the Convention itself.

An example of such a finding is the judgment in Soderman v. Sweden (12 November, 2013), which was taken following an application by the applicant alleging a breach by the State of its positive obligations in connection with the signing of the Convention. The applicant insisted that the State party had failed to provide her with adequate protection against the violation of her inviolability as a result of her stepfather's attempt to film the applicant naked at the age of 14. The ECtHR agreed with the respondent State's position that the stepfather's actions did not involve physical violence or 
corruption, but that the applicant's inviolability had nevertheless been violated. The aggravating circumstances of the ECtHR acknowledged that the offense had been committed against a minor by a close person at her home, that is, in a place where the applicant should have felt safe.

The case-law of the European Court of Human Rights has played an important role as a catalyst for crimes against sexual freedom and the integrity of the child that has taken place in educational institutions. In this context, the case of O'Keeffe v. Ireland (28 January, 2014), in which the ECtHR concluded on a complaint of sexual violence suffered by the applicant during her studies at a state-funded school but administered by the Catholic Church, is illustrative. In resolving the case, the ECtHR found that the State had violated the provisions of the Convention because, in the ECtHR's view, the respondent State should have been aware of the potential risks of sexual violence in schools and ensured effective monitoring of teachers' behavior towards children.

In some cases, complaints to the ECtHR relate to an imperfect criminal investigation mechanism. Thus, in the decision in the case M.C. and Others v. Bulgaria (4 March, 2003), the ECtHR found the defendant in breach because the law, case law, and investigation were imperfect.

Unfortunately, the ECtHR did not stay away from the attention of Ukraine, which was the defendant in the case M.S. v. Ukraine (11 october, 2017). Although the case concerned the determination of the child's place of residence, it touched on issues of violation of sexual freedom and inviolability. The ECtHR acknowledged the pre-trial investigation into the sexual abuse of the applicant's child, who had suffered from the pressure and behavior of the mother's roommate. In its judgment, in this case, the ECtHR noted numerous violations of Ukraine's obligations under the Convention due to the ineffectiveness of the pre-trial investigation:

- it was not thorough, as evidenced by numerous referrals for further investigation following the reversal of the closure decisions.

- late, as certain investigative actions, in particular a forensic psychiatric examination, which led experts to conclude that the girl could have given true testimony (acknowledging that she did not understand the significance of what was happening due to her age), were carried out approximately 2 years later, after the event and for such delays, there were no excuses, and;

- the length of the proceedings was excessive.

Analyzing the practice of the ECtHR, we can conclude that the state is not an exception when the state is condemned for gaps in the legislation that do not allow children to fully feel the protection of their rights. 
Yuliia Chornous, Hanna Nikitina-Dudikova, Olena Lepei, Anastasiia Antoniuk y Mariia Fridman-Kozachenko

676

Investigation of sexual crimes against children

According to the author, the protection of children's rights to their sexual freedom and inviolability includes the implementation of preventive measures aimed at stopping the commission of an offense.

Article 34 of the UN Convention on the Rights of the Child (United Nations, 1989) states that States parties have an obligation to protect the child from all forms of sexual exploitation and sexual abuse. To this end, States Parties shall take at the national, bilateral, and multilateral levels all necessary measures to prevent:

a) inducing or forcing a child to engage in any unlawful sexual activity.

b) the use of children for exploitation in prostitution or other unlawful sexual practices, and;

c) the use of children for the purpose of exploitation in pornography and pornographic materials.

In view of the above, as well as given the main objectives of the policy in the field of protection of children's rights, preventive measures to prevent violations of sexual freedom and inviolability of the child should be aimed at exposing:

- the abduction of children, even by parents and parents; sexual exploitation of children.

- organizations involved in child trafficking.

- Internet networks and enterprises engaged in the production, trade, distribution and/or sale of child pornography.

- child sex tourism (international sexual travel for children); production of child pornography, including coercion/enticement of a minor.

- trafficking in child pornography.

- distribution of child pornography.

- possession of child pornography, etc.

It is also important to establish and ensure an organized and clear mechanism for responding to reports of a crime concerning sexual freedom and inviolability of the child, and well-established tactics and sets of investigative actions that will lead to an effective and rapid investigation of these crimes.

Denisovskyi and Fedchak (2018), conducting research, found that scientists and practitioners indicate that the results of operational prevention of crimes against morality are unsatisfactory. This is, primarily, due to the lack of interest of law enforcement officers in such work, as the 
prevention of criminal intent and the use of preventive measures is difficult to confirm, especially in terms of reporting.

Another negative factor is the lack of an effective mechanism for interaction and coordination of measures taken by law enforcement agencies among themselves and with international law enforcement agencies, international and non-governmental organizations. An equally significant problem in this context is the lack of material and technical support for the prevention of crimes against sexual freedom and sexual integrity, in particular, the sexual freedom and sexual integrity of minors and juveniles of our society.

It is worth noting that the psychology of a criminal's behavior is related to situations that arose long before he committed the crime. In this regard, the prevention of crimes against sexual freedom and the integrity of the child is the responsibility not only of law enforcement agencies but also of other authorities, educational institutions, enterprises, institutions, and organizations dealing with children.

Thus, the positive dynamics in the prevention of crimes against sexual freedom and the inviolability of the child will be provided by the identification and prior active work with disadvantaged families in which a situation may arise that would lead to a violation of the rights of the child.

According to the authors, it is also necessary to introduce sex education lessons in schools to help identify children suffering from sexual violence or its initial manifestations, to instill in children an understanding of normal sexual relations, which in the future in the case of encroachment on sexual freedom and inviolability the child will have the ability to understand the illegality of the actions. Periodic conversations with children about how to act in such situations should also be mandatory to avoid negative consequences and prevent the commission of the crime itself.

As children of all ages suffer from sexual crimes, prevention of the above-mentioned crimes should be carried out with the parents or legal representatives of the children, regardless of the social status of the family.

Dzhuzha (2009) emphasizes that many parents are unaware of their legal rights and freedoms, the procedure for processing applications and appeals of citizens by law enforcement agencies. Combined with the mental shock they typically experience when their children become victims of crime, this leads to law enforcement allegations that law enforcement officials do not always report child abuse. Because of this, there is an urgent need to create specialized centers where child victims of crime and their parents could receive free timely qualified psychological and legal assistance.

The above indicates the need to create a strong system of juvenile justice in Ukraine, which, according to Krestovska (2008), is a system of 
Yuliia Chornous, Hanna Nikitina-Dudikova, Olena Lepei, Anastasïa Antoniuk y Mariia Fridman-Kozachenko

state, municipal and public, judicial, law enforcement and human rights bodies, institutions, and organizations based on juvenile law and with the help of medical, social and psychological-pedagogical methods administer justice for children, prevention and prevention of offenses against and against children, protection of rights, freedoms, and interests, as well as resocialization of children in difficult life situations

Law, as a system of mandatory rules of conduct introduced or sanctioned by the state, is the most effective regulator of public relations. No other social norms, such as traditions, customs, norms of morality, etc., can regulate and ensure the protection of various social relations as the rules of law do (Tkalych et al., 2020). The creation of the EU was a triumph for the principles of liberal democracy. Postwar Europe has become one of the most developed regions and for many years has been a magnet for people from all over the world (Shyshka and Tkalych, 2020). Ukraine's path to membership in the European Union is constitutionally enshrined. Nevertheless, to be a member of the EU, it is necessary to comply with the requirements of the Union and to harmonize legislation (Pavlova et al., 2020). Currently, juvenile justice institutions in Ukraine are generally developing at a slow pace and rather one-sidedly, i.e. only within the framework of criminal proceedings against minors, while other offenses committed by third parties against minors are ignored, which entails the inability to create an effective mechanism for the protection of children's rights, taking into account their special legal status.

In particular, as a result, the representative of the Verkhovna Rada Commissioner for Human Rights for the Rights of the Child and Family, Filipishyna during a round table in the Committee on Law Enforcement, held by video conference on September 22, 2020, stated that the percentage of crimes of sexual the nature of the violation of the rights of the child is unsatisfactory. Thus, the representative noted that according to the Office of the Prosecutor General during January-August 2020, 147 children were victims of rape. Instead, for the whole of 2019, the number of children affected by this crime was 148. Filipishyna also noted that as of August 2020, 44 criminal proceedings were registered under Article 155 of the Criminal Code of Ukraine "sexual intercourse with a person who has not reached sexual maturity” (Law Enforcement Committee, 2020).

\section{Conclusions}

Protection and defense of the rights of the child is one of the primary tasks of the state. At the same time, the level of crime, which is subject to sexual freedom and inviolability, has recently been unsatisfactory, so there is a need to develop clear mechanisms for detecting, investigating, and preventing these crimes. 
The case-law of theECtHR is currently replete with precedents concerning children's rights, in particular to sexual freedom and inviolability, indicating a low level of protection and protection by many States.

The problem of detecting sexual crimes against children is the default of children, parents, or other authorities and persons who have learned the relevant information, the reluctance of parents to report the crime due to the possible condemnation by society, and potential future consequences for the child in the event of accidental disclosure of information about the crime.

Investigations of crimes against the sexual freedom and inviolability of children should be carried out taking into account the specifics of the crime and the psychological characteristics of the child. Therefore, it is of great importance that the authorized person of law enforcement agencies understands the psychology of the child and the ability to create a trusting atmosphere when carrying out appropriate investigative actions, in particular, the interrogation of the child.

Effective prevention of crimes against sexual freedom and inviolability of the child can be achieved by creating an extensive system of juvenile justice, clear consolidation of their powers and responsibilities, focusing law enforcement on the prevention of such crimes, proper material, technical and methodological support of relevant bodies, institutions and organizations that work with children, sex education of children, periodic interviews with parents / legal representatives.

\section{Bibliographic References}

DENISOVSKYI, Mykhailo; FEDCHAK, Ivan. 2018. The essence and prevention of crimes against sexual freedom and sexual integrity of minors and juveniles. Lviv State Department of Internal Affairs. Lviv, Ukraine.

DUDOROV, Oleksandr. 2018. Crimes against sexual freedom and sexual integrity of a person (basic provisions of criminal law). Luhansk State University of Internal Affairs named after E.O. Didorenko. Severodonetsk, Ukraine.

DZHUZHA, Oleksandr. 2009. Prevention of crimes related to sexual violence. Attica. Kyiv, Ukraine.

EUROPEAN COURT OF HUMAN RIGHTS. 1985. X AND Y v. THE NETHERLANDS. (Application no. 8978/80) 26 March 1985. Available online. In: https://cutt.ly/DjvekdS. Consultation date: 28/11/2019. 
Yuliiia Chornous, Hanna Nikitina-Dudikova, Olena Lepei, Anastasïa Antoniuk y Mariia Fridman-Kozachenko

680

Investigation of sexual crimes against children

EUROPEAN COURT OF HUMAN RIGHTS. 2003. M.C. v. Bulgaria. (Application no. 39272/98) 4 march 2004. Available online. In: https:// cutt.ly/bjvwFPC. Consultation date: 28/11/2019.

EUROPEAN COURT OF HUMAN RIGHTS. 2013. SÖDERMAN v. SWEDEN. (Application no. 5786/o8) 12 November 2013. Available online. In: https://cutt.ly/Gjveu1K. Consultation date: 26/11/2019.

EUROPEAN COURT OF HUMAN RIGHTS. 2014. O'KEEFFE v. IRELAND. (Application no. 35810/o9) 28 January 2014. Available online. In: https://cutt.ly/xjvw2eZ. Consultation date: 26/11/2019.

EUROPEAN COURT OF HUMAN RIGHTS. 2017. M.S. v. UKRAINE. (Application no. 2091/13) 11 october 2017. Available online. In: https:// cutt.ly/cgkgfW8. Consultation date: 28/11/2019.

HUMAN, Roman. 2016. "Violence against children in state custody" In: Amnesty International Bulletin. Vol. 48, pp. 4-10.

KRESTOVSKA, Nataliia. 2008. Juvenile law of Ukraine: genesis and current state. Academia jurídica de Odessa. Odessa, Ukraine.

LAW ENFORCEMENT COMMITTEE. 2020. Criminal protection of children from sexual exploitation and prevention of re-victimization of children during criminal proceedings. Available online. In: https://www.rada. gov.ua/news/news_kom/197895.html. Consultation date: 28/11/2020.

LAW OF UKRAINE. 1996. Law 27-IX/1996 of January 1, Constitution. Available online. In: https://zakon.rada.gov.ua/laws/show/254\%Do\%BA/96\%Do\%B2\%D1\%80\#Text. Consultation date: 28/11/2019.

LAW OF UKRAINE. 2001. Law 2147a-VIII/ 2001 of December 30, Criminal Code. Available online. In: https://zakon.rada.gov.ua/laws/show/234114/stru\#Stru. Consultation date: 28/11/2019.

LAW OF UKRAINE. 2001. Law 2402-III/2001 of April 26, On Child Protection. Available online. In: https://zakon.rada.gov.ua/laws/show/240214\#Text. Consultation date: 28/11/2019.

LAW OF UKRAINE. 2012. Law 4651-VI/2012 of April 13, Criminal Procedure Code of Ukraine. Available online. In: https://zakon.rada.gov.ua/laws/ show/4651-17\#Text. Consultation date: 28/11/2019.

ORTYNSKYI, Volodymyr; CHORNOUS, Yuliia; PAVLIUK, Nataliia. 2018. "International Cooperation In: Financial Fraud Investigation" In: Baltic Journal of Economic Studies. Vol. 4, No. 4. pp. 252-257. 
PAVLOVA, Yuliia; POLUNINA, Olha; TKALYCH, Maxym; MANKOVSKYI, Volodymyr; ZUBAIR, Akhmad. 2020. "International-legal standards of cooperation of ukraine in the field of environmental (climate) problems" In: Amazonia Investiga. Vol. 9, No. 25, pp. 295-301. Available online. In: https://amazoniainvestiga.info/index.php/amazonia/article/ view/1069. Consultation date: 20/02/2020.

SHAPOVALOV, Oleksii. 2017. "Identification of signs of crimes in the process of pre-trial investigation" In: Legal Journal of the National Academy of Internal Affairs. Vol. 13, No. 1, pp. 99-107.

SHYSHKA, Roman; TKALYCH, Maxym. 2020. The World in 2020: What Are The Threats To Humanity? In: Amazonia Investiga. Vol. 9 No. 26. pp. 3-5. Available online. In: https://amazoniainvestiga.info/index.php/ amazonia/article/view/1132. Consultation date: 20/02/2020.

TKALYCH, Maxym; SAFONCHYK, Oksana; TOLMACHEVSKA, Yuliia. 2020. "Private Law and human rights: New realities" In: DIXI. No. 2, pp. 1-12.

UNITED NATIONS. 1950. Convention for the Protection of Human Rights and Fundamental Freedoms. Available online. In: https://www.echr.coe.int/ documents/convention_eng.pdf. Consultation date: 28/11/2019.

UNITED NATIONS. 1989. Convention on the Rights of the Child. Available online. In: https://www.ohchr.org/en/professionalinterest/pages/crc. aspx?fbclid=IwAR35cVUouzhmgWieqVBgZYcB2BoAxOmowoWCMu4 zy7eIWfQD-VMAwGkORks. Consultation date: 28/11/2019.

UNITED NATIONS. 2000. Optional Protocol to the Convention on the Rights of the Child on the sale of children, child prostitution and child pornography. Available online. In: https://www.ohchr.org/en/professionalinterest/ pages/opsccrc.aspx. Consultation date: 28/11/2019. 

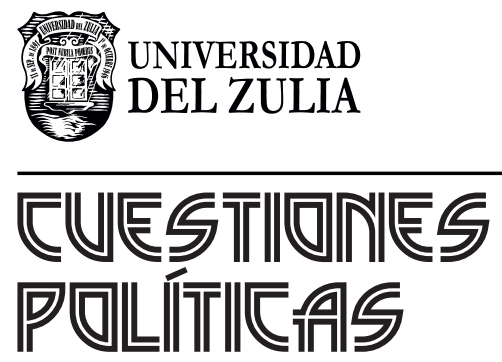

Vol.39 No 68

Esta revista fue editada en formato digital y publicada en enero de 2021, por el Fondo Editorial Serbiluz, Universidad del Zulia. Maracaibo-Venezuela 